\title{
Effect of Direct and Indirect Compensation for Performance of Employees PT. Terminal Petikemas Surabaya
}

\author{
Bagus Angan Brasilio and Hermien Tridayanti \\ Faculty of Economic and Business, Narotama University \\ Surabaya, Jawa Timur \\ brasiliobagus@gmail.com, hermien.tridayanti@narotama.ac.id
}

\begin{abstract}
The purpose of this study is to analyze the effect of direct and indirect compensation on employee performance simultaneously and partially. The population in this study was 92 employees. This study uses a quantitative approach. The object of this research is direct compensation and indirect compensation at PT. Surabaya Container Terminal. The data collection methods used were questionnaires and interviews. The data analysis technique used is multiple linear regression. The results of the study are that direct compensation has a positive and significant effect on employee performance, and indirect compensation has a positive and significant effect on employee performance. To improve employee performance, companies can maintain and improve indirect compensation services, because indirect compensation has a dominant influence in influencing employee performance, such as improving employee welfare, paying attention to what employees need now, then the company can provide indirect compensation in return for employee services that have been provided to the company.
\end{abstract}

Keywords:

Direct Compensation, Indirect Compensation, Performance

\section{Introduction}

In modern times many companies are competing against each other to be the best. Various methods are used so that the company he runs experiences advances and can develop rapidly, and can compete with other companies. The existence of human resources in a company plays a very important role because the workforce has a large role to carry out company activities. The potential of every human resource in the company must be utilized as well as possible in order to be able to provide optimal output. Employee performance is very important in the company to achieve the company's goals. Therefore, to achieve this goal, the company always connects compensation with employee performance so that employee performance can be maintained. The achievement of company goals does not only depend on modern equipment but also depends on the quality of human resources. The success of an organization is strongly influenced by the performance of each of its employees. Every organization and company will always try to improve employee performance, with the hope that what the company's goals will be achieved

Providing compensation is not a simple problem but rather complex, therefore every company must have guidelines on how to determine the right compensation system, so that with the right reward system, employee productivity is expected to increase. Basically everyone who works wants to get fair compensation.

Considering the important role of labor for companies, then aspects oriented to compensation need to get serious attention from the organization or company, because by providing appropriate compensation. According to Kadarisman, 2018 "in general the purpose of compensation management is to help companies achieve their strategic success goals and ensure external and internal justice". So that the provision of compensation is expected to improve the performance of employees / employees of the RTG operator section which in turn has an impact on company performance. Instead the size of the compensation can affect performance, motivation and job satisfaction. The definition of performance (work performance) as a result of work in quality and quantity achieved by an employee in carrying out their duties in accordance with the responsibilities given (Muah, 2015)

Companies and employees essentially need each other, employees are company assets because without the presence of human resources, the company will not be able to run, nor can employees support their welfare without the company as a place to make a living as well as the implementation of their own scientific disciplines. Then employees must pay attention to their welfare, not only to be required with various kinds of workloads, as well as employees who do not only claim their rights but work and responsibilities as employees are not completed. But 
there are still companies that pay less attention to their employees so that employees become motivated, lazy, and seemingly not doing well. So they assume that no matter how hard they work the company does not care about them, let alone to provide welfare and rewards that are appropriate for them and make motivation for employees. Employee welfare at PT. Surabaya Container Terminal, especially employees on the operator's side, is not given much attention, as an example of a case that has occurred, namely employees of PT Terminal Petikemas Surabaya about incentives and shift allowances provided are not in accordance with the workload provided by the company. whereas in the company's own policies, benefits and incentives have become obligations that must be given to employees, especially employees of the company's operations. Seeing this phenomenon researchers want to find out whether direct compensation and indirect compensation will affect employee performance against the workload provided by the company.

\section{Literature Review}

\section{a. Direct Compensation (X1)}

Direct compensation is remuneration provided by the company to employees / employees in the form of finance. Providing financial compensation to employees of the RTG Operator section of PT. Surabaya Petikema Terminal consists of salary, and incentives.

1) Principal Payment (in the form of salary)

a) Salary received by employees in the company, if associated with the amount of employee responsibility.

b) Salaries received by employees in the company, if related to the length of service.

2) Pay incentives (in the form of premiums and bonuses)

a) Incentives given to Employees in the company, if related to the timeliness of giving commissions.

b) Incentives given to employees in the company, if associated with production targets set by the company.

\section{b. Indirect Compensation (X2)}

Indirect compensation given to employees in the company is in the form of benefits, including all benefits received by employees outside the basic salary, commissions, and bonuses.

1) Protection programs such as health benefits.

2) Work accident insurance.

3) Pay outside working hours.

4) Facilities.

Measurement of each indicator in variable $\mathrm{X}$ is measured based on Employee answers to questions in the questionnaire specified in the scoring and measured using a Likert scale.

\section{c. Performance (Y)}

Performance is the result of work achieved by employees in carrying out tasks and responsibilities based on the measurements used on the work in question. While the operational definition of employee performance itself is the level of employee performance in PT. Surabaya Container Terminal has a good performance sourced from (E Edison, Y Anwar, 2016). According to (E Edison, Y Anwar, 2016) employee performance is influenced by several factors, namely:

1) Quality of Work

2) Quantity of work

3) Job Knowledge

4) Teamwork

5) Creativity

6) Innovation

7) Initiative

Thus, in this study using the following performance variable indicators:

1) Work quality

2) Service quality

3) Timing

4) Accuracy of work

5) Initiative at work

6) Understanding of tupoksi (main tasks and functions)

7) Work ability

8) Knowledge and skills 
VOLUME 2 | NUMBER 2 | MARCH 2020

Available online at

http://proceedings.worldconference.id.

9) Work communication

\section{d. Hypotheses}

1) H1: There is a significant partial effect between direct compensation on the performance of PT. Surabaya Container Terminal.

2) H2: There is a significant partial effect between indirect compensation on the performance of the employees of PT. Surabaya Container Terminal.

3) H3: There is a significant simultaneous effect between direct compensation and indirect compensation on the performance of PT. Surabaya Container Terminal.

\section{e. Research Conceptual Framework}

Remarks:

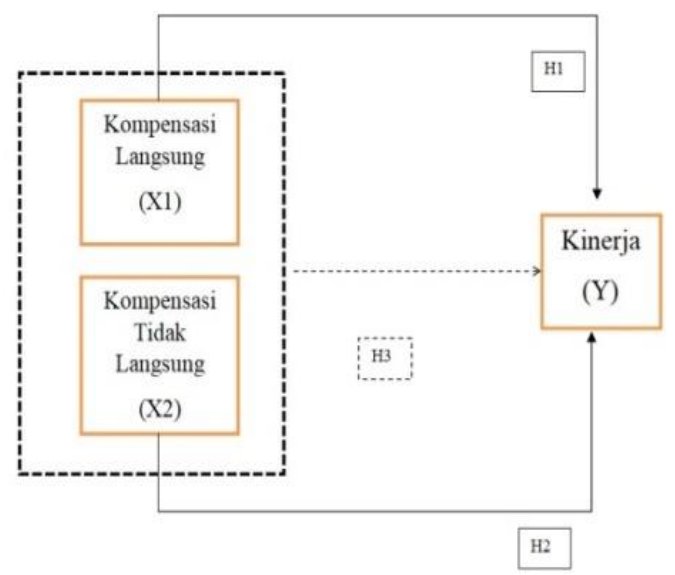

Figure 1. Research Conceptual Framework

$\longrightarrow \quad:$ Partially

: Simultaneously

\section{Methodology}

This study uses a quantitative approach. The object of this research was conducted at PT. Surabaya Container Terminal with a population of 92 people. Data collection techniques by interviewing and distributing questionnaires. This type of data measurement uses a Likert scale. For processing the data using SPSS version 25. The data were analyzed with multiple linear regression analysis to test the validity, reliability, test the classical assumption of normality test, heteroscedasticity, multicollinearity test, correlation analysis and determination consisting of $\mathrm{F}$ test and t test.

\section{Result and Discussion}

\section{a. Reliability and Validity Test}

The data used in this study using SPSS version 16 o'clock with the type of data that is processed Method of Successive Interval, to facilitate the processing of data in order to explain the results of respondents of the variables to be studied.

1) Relability Test

According to (Winarno, 2018) relability testing with internal consistency is done by trying the instrument once and then the data obtained is analyzed with certain techniques. To assess the reliability of internal consistency among the questions in this study the Croanch's alpha (alpha coefficient) technique was used. Alpha coefficients vary from 0 to 1, a measurement item is said to be reliable if it has an alpha coefficient value (a) greater than 0.6. The research data has Cronbach alpha of each variable above 0.6, so the research data can be said to be reliable and reliable. 


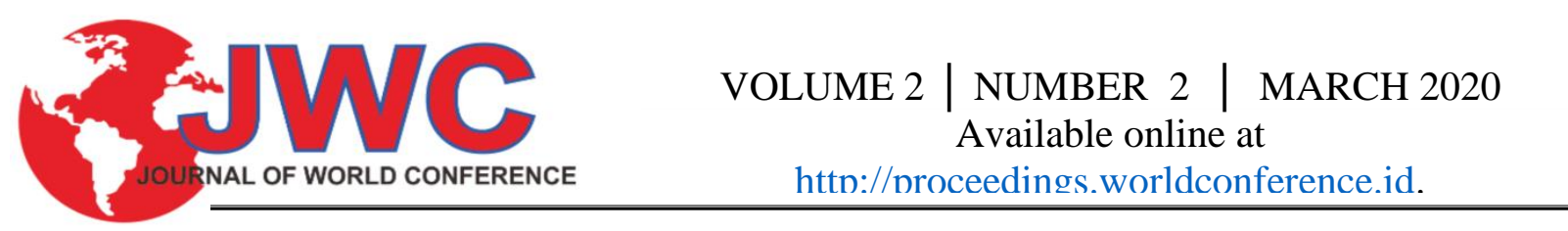

2) Validity Test

Validity testing is very necessary in a study, especially those using questionnaires to obtain data. Validity testing is intended to determine the validity between concepts and empirical reality.

Validity Test in this study was conducted by calculating the correlation between item scores with total scores (overall items) item questions in one variable. The correlation technique used in the validity test is the product moment correlation technique from Karl Pearson. (Winarno, 2018)

Validity testing can be done by correlating each factor or variable with the total factor or variable using the correlation (r) product moment. Testing criteria to accept or reject the hypothesis that a statement is valid or cannot be done by:

H0: $r=0$, there is no valid data at the error rate $(\alpha)$ of $5 \%$.

$\mathrm{H} 1: \mathrm{r} \neq 0$, there are valid data at an error rate $(\alpha)$ of $5 \%$.

The null hypothesis (H0) is accepted if $\mathrm{r}$ arithmetic $<\mathrm{r}$ table, and vice versa alternative hypothesis (H1) is accepted if $r$ arithmetic $>r$ table.

Validity testing is done by using the SPSS program ver. 25.0 by using product moment correlation produces the value of each statement item with the overall question item score.

Based on the calculation table using spss, it can be seen that the value of sig. $r$ question items are smaller than $0.05(\alpha=0.05)$ and $r$ count $>\mathrm{r}$ table which means that each variable item is valid, so it can be concluded that these items can be used to measure the research variables.

\section{b. Classic assumption test}

This classic assumption test must be carried out to fulfill the use of multiple linear regression. After holding multiple regression calculations through SPSS ver. 25.0 thereafter a classical regression assumption test is held. The test results are presented as follows:

1) Normality test

Based on the P-P Plot test it was found that the data points had spread along a diagonal line, so that it was said that the residuals had spread in a normal distribution. The normality test results in this study can be seen in the Table below:

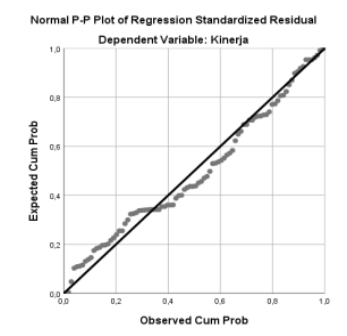

Figure 2. Normality Test

Source: Primary Data Processed SPSS version 25.0

2) Multicollinearity Test

This Multicollinearity Test is conducted to find out that there is no very strong relationship or no perfect linear relationship or it can also be said that the independent variables are not interrelated. The method of testing is to compare the tolerance value obtained from the multiple regression calculation, if the tolerance value> 0.1 then multicollinearity occurs.

Table 1. Multicollinearity Test Results Table

\begin{tabular}{|c|c|c|}
\hline \multirow{2}{*}{$\begin{array}{c}\text { Independent } \\
\text { variable }\end{array}$} & \multicolumn{2}{|c|}{ Collinearity Statistics } \\
\cline { 2 - 3 } & Tolerance & VIF \\
\hline $\mathrm{X} 1$ & 0.762 & 1.312 \\
\hline $\mathrm{X} 2$ & 0.762 & 1.312 \\
\hline
\end{tabular}

Source: Primary Data Processed SPSS version 25.0

Based on the table above, here are the test results for each independent variable:

a) Tolerance for Direct Compensation (X1) is 0.762 


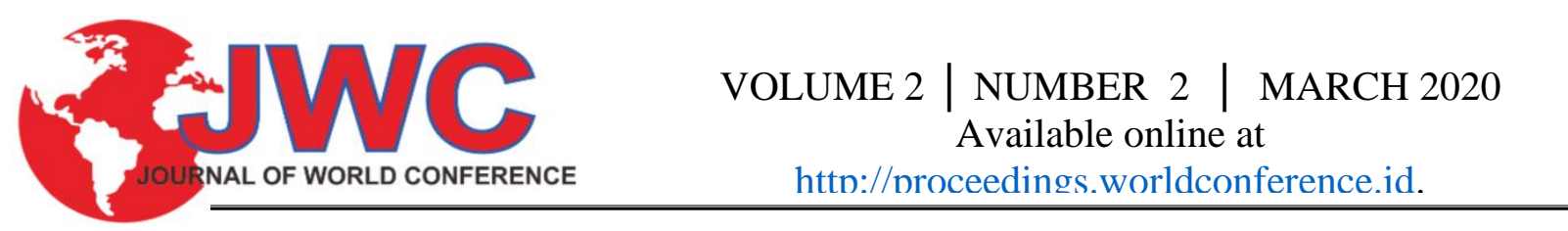

b) Tolerance for Indirect Compensation (X2) is 0.762

In the test results obtained that the overall tolerance value $>0.1$ so that it can be concluded that there is no multicollinearity between independent variables. Multicollinearity test can also be done by comparing the value of VIF (Variance Inflation Factor) with the number 10. If the VIF value $<10$ then multicollinearity occurs. Following are the results of testing each independent variable:

a) The VIF for Communication is 1,312

b) VIF for Job Satisfaction is 1,312

From the test results it can be concluded that there is no multicollinearity between independent variables. Thus the assumption test of the absence of multicollinearity can be fulfilled.

3) Heterokedasticity Test

Heterokedastisitas test is used to determine whether there is an inequality of residual deviation values due to the size of one of the independent variables. Or there is a difference in the value of variance with the increasing value of the independent variable. The test procedure is done by scatter plot test. Homogeneity testing of the various forms is based on the hypothesis:

Table 2. Image of Heteroscedasticity Test Results

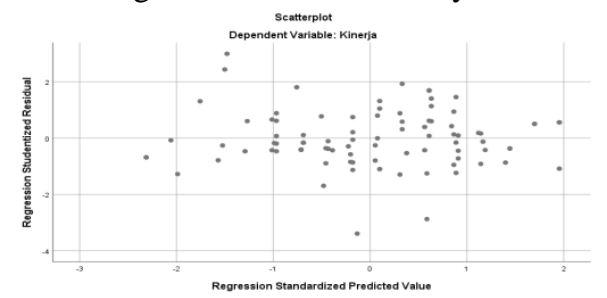

Source: Primary Data Processed SPSS version 25.0

From the test results it was found that the scatterplot display diagram spreads and does not form a particular pattern then heteroscedasticity does not occur. So it can be concluded that the remainder has a homogeneous variety (constant) or in other words there are no symptoms of heterokedastisitas. With all the classic regression assumptions above fulfilled, it can be said that the multiple linear regression model used in this study is already feasible or appropriate. So that interpretation can be taken from the results of multiple regression analysis that has been done.

\section{c. Multiple Linear Regression Analysis}

The multiple linear method is used to determine the effect of the independent variables between the direct and indirect compensation program factors on the variable, namely performance. Multiple linear regression analysis was used in this study with the aim to prove the hypothesis about the influence of the variable Direct Compensation (X1), Indirect Compensation (X2) partially or simultaneously on Employee Performance (Y). A summary of data management using SPSS in this study is shown in table 4.8 as follows:

Based on Table 4.8 the regression equation is obtained as follows:

$\mathrm{Y}=9,244+0,807 \mathrm{X} 1+0,879 \mathrm{X} 2$

From the above equation can be interpreted as follows:

1) A constant of 9,244, meaning that if direct compensation (X1) and indirect compensation (X2) are constant then the performance is 9,244 .

2) $\mathrm{b} 1=0.807$, meaning that Employee Performance will increase by 0.807 units for each additional one unit $\mathrm{X} 1$ (direct compensation). So if Compensation has increased by 1 unit, then Employee Performance will increase by 0.807 units assuming the other variables are considered constant.

3) $\mathrm{b} 2=0.879$, Employee Performance will increase by 0.879 units for each additional one unit X2 (Indirect Compensation), So if Job Satisfaction has increased by 1 unit, Employee Performance will increase by 0.879 units assuming the other variables are considered constant.

\section{d. Hypothesis Test F test}

Aims to determine the feasibility of multiple linear regression models as an analytical tool that tests the effect of independent variables (independent) on the dependent variable (bound) together. When $\mathrm{F}$ counts $<\mathrm{F}$ table. Then $\mathrm{HO}$ is accepted and $\mathrm{Ha}$ is rejected, meaning there is no simultyan influence. If $\mathrm{F}$ arithmetic $>\mathrm{F}$ table then $\mathrm{H} 0$ is rejected and $\mathrm{Ha}$ is accepted, meaning there is a simultaneous influence. 


\section{VOLUME 2 | NUMBER 2 | MARCH 2020 \\ Available online at \\ http://proceedings.worldconference.id.}

Based on the above output it is known that the significance value (Sig) in the F test is 0,000 . Because Sig. $0.000<0.05$, then as the basis for decision making in the $\mathrm{F}$ test it can be concluded that Direct Compensation (X1) and Indirect Compensation (X2) simultaneously affect Performance (Y) or significant means. Thus, the requirements so that we can interpret the coefficient determination in multiple linear analysis has been fulfilled.

\section{T Test}

The $\mathrm{T}$ test is a regression coefficient test used to find out whether the independent variable (X) individually influences the dependent variable (Y).

H1: Compensation has a significant effect on employee performance

H2: Leadership style significantly influences employee performance

a. Based on the SPSS output table "Coefficients" above known value of 4.006 with a Significant value (Sig.) Direct Compensation variable (X1) of 0,000 < probability 0.05 then rejected and Ha accepted means that direct compensation has a partially significant effect on employee performance. Thus the second hypothesis that the authors propose that "Direct Compensation significantly influences Employee Performance (Y)" empirically proven its truth.

b. Based on the SPSS output table "Coefficients" above is known to be a value of 4.124 with a Significant value (Sig.) Indirect Compensation variable (X2) of $0.000>$ probability 0.05 then rejected and Ha accepted means that Indirect Compensation (X2) has a significant effect partial on employee performance (Y). Thus the second hypothesis that the authors propose that "Indirect Compensation (X2) significantly influences Employee Performance (Y)" is proven empirically correct.

\section{e. Discussion of Results}

1) The Effect of Direct Compensation (X1) on Employee Performance (Y)

Based on the calculation, it is known that the value of 4.006 with the Significant value (Sig.) Of the Direct Compensation variable (X1) is 0,000 <probability 0.05 , then rejected and Ha accepted means that direct compensation has a partially significant effect on Employee performance. Thus the second hypothesis that the authors propose that "Direct Compensation (X1) significantly influences Employee Performance (Y)" is proven empirically correct.

It can be interpreted that Direct Compensation owned by PT Terminal Petikemas Surabaya has an effect on the employee's performance as indicated by the employee's ability to complete the work and the workload provided to achieve the company's targets.

2) The Effect of Indirect Compensation (X2) on Employee Performance (Y)

Based on the calculation results it is known the value of 4.124 with a Significant value (Sig.) Direct Compensation variable (X2) of 0,000 <probability 0.05 then rejected and $\mathrm{Ha}$ accepted means that direct compensation has a partially significant effect on Employee performance. Thus the second hypothesis that the authors propose, "Indirect Compensation (X2) significantly influences Employee Performance (Y)" is proven empirically correct.

It can be interpreted that Indirect Compensation owned by PT Terminal Petikemas Surabaya has an effect on the employee's performance as indicated by the employee's ability to complete the work and the workload provided to achieve the company's targets.

3) Effect of Direct Compensation (X1) and Indirect Compensation (X2) simultaneously affect Performance (Y)

Based on calculations that have been done, it is known that the significance value (Sig) in the F test is 0,000. Because Sig. $0.000<0.05$, then as the basis for decision making in the $\mathrm{F}$ test it can be concluded that Direct Compensation (X1) and Indirect Compensation (X2) simultaneously affect Performance (Y) or significant means. Thus, the requirements so that we can interpret the coefficient determination in multiple linear analysis has been fulfilled.

\section{Conclusions and Suggestions \\ a. Conclusions}

This research was conducted to find out which variables have an effect on employee performance. In this study the independent variable used was the Direct Compensation variable (X1) and Indirect Compensation (X2) while the dependent variable used was Performance $(Y)$. Based on the calculation of multiple linear regression analysis, it can be seen: 


\section{VOLUME 2 | NUMBER 2 | MARCH 2020 \\ Available online at \\ http://proceedings.worldconference.id.}

1) Based on the results obtained that the variable Direct Compensation (X1) and Indirect Compensation (X2) have a significant effect simultaneously on Employee Performance (Y). So it can be concluded by increasing Direct Compensation (X1) and Indirect Compensation (X2), it will improve Employee Performance.

2) Based on the partial $t$ test results found that Direct Compensation (X1) gives a significant influence partially on Employee Performance.

3) Based on the partial t-test results it was found that Indirect Compensation (X2) had a significant influence partially on Employee Performance.

\section{b. Suggestions}

Based on the conclusions above, several suggestions can be put forward that can be useful for the company and for other parties. As for the suggestions given, they include:

1) It is expected that the company can maintain and improve services to Indirect Compensation, because the Indirect Compensation variable has a dominant influence in influencing Employee Performance, such as increasing welfare for employees such as paying attention to what employees currently need, therefore the company can provide indirect compensation in return for employee services that have been provided to the company.

2) Considering that the independent variables in this study are very important in influencing performance, it is expected that the results of this study can be used as a reference for future researchers to develop this research by considering other variables which are other variables beyond the variables included in this study. .

\section{Reference}

Alini. (2015). Pengaruh Kompensasi Terhadap Kinerja Karyawan ( Studi Pada Hotel Kartika Chandra Jakarta ). EProceeding of Management Vol.2 No.1 April 2015, 671, 2(1), 671-685.

Barlian, E. (2016a). METODOLOGI penelitian kuantitatif \& kualitatif. Padang: Sukabina Press.

Barlian, E. (2016b). Mrtodologi Penelitian Kuantitatif dan Kualitatif. Padang: Sukabina Press.

Bustamam, F. L., Teng, S. S., \& Abdullah, F. Z. (2014). Reward Management and Job Satisfaction among Frontline Employees in Hotel Industry in Malaysia. Procedia - Social and Behavioral Sciences, 144, 392-402. https://doi.org/10.1016/j.sbspro.2014.07.308

Dwi Dharma Wiguna, I. K., Eka Mahadewi, N. P., \& Sofia Wijaya, N. M. (2016). Pengaruh Kompensasi Terhadap Kinerja Di Pt Bali Daksina Wisata. Jurnal IPTA, 4(2), 78. https://doi.org/10.24843/ipta.2016.v04.i02.p16

E Edison, Y Anwar, I. K. (2016). Manajemen Sumber Daya Manusia. Bandung: Alfabeta.

Edrick Leonardo dan Fransisca Andreani. (2015). Identification of electric quadrupole O2 and N2 lines in the infrared atmospheric absorption spectrum due to the vibration-rotation fundamentals. PENGARUH PEMBERIAN KOMPENSASI TERHADAP KINERJA KARYAWAN PADA PT. KOPANITIA, 3(1), 28-35. https://doi.org/10.1029/GL008i001p00077

Gusmão, J. F., \& Riana, G. (2018). Pengaruh Kompensasi Terhadap Motivasi Dan Kinerja Pegawai Administrasi Di Dinas Pendidikan Distrik Baucau Timor Leste. Jurnal Buletin Studi Ekonomi, 23(1), 138-153.

Kadarisman, M. D. (2018). Manajemen Kompensasi (2nd ed.). Jakarta: PT Raja Grafindo Persada.

Kituma Merera JALETA, Chalchissa Amentie, \& Kumera, L. (2019). EFFECT OF NON- FINANCIAL COMPENSATION ON THE EMPLOYEES ' JOB PERFORMANCE: A CASE OF JIMMA GENETI WOREDA HEALTH CENTERS IN HORRO GUDURU, ETHIOPIA Chalchissa Amentie KERO Lalise KUMERA International International of Commerce of Commerce and and Finance Fi. 5(2), 31-44.

Muah, M. \&. (2015). Manajemen Sumber Daya Manusia (Cetakan Pe). Zifatama Publisher.

Muah, M. \&. (2017). manajemen Sumber Daya Manusia Profesional. Sidoarjo: Zifatama Publisher.

Riana, N., Fajri, K., \& Alsyaumi, K. (2017). Pengaruh Kompensasi Terhadap Kinerja Karyawan Di Kampung Batu Malakasari Tektona Waterpark Kabupaten Bandung. Tourism Scientific Journal, 2(1), 1. https://doi.org/10.32659/tsj.v2i1.15

Samnani, A. K., \& Singh, P. (2014). Performance-enhancing compensation practices and employee productivity: The role of workplace bullying. Human Resource Management Review, 24(1), 5-16. https://doi.org/10.1016/j.hrmr.2013.08.013 


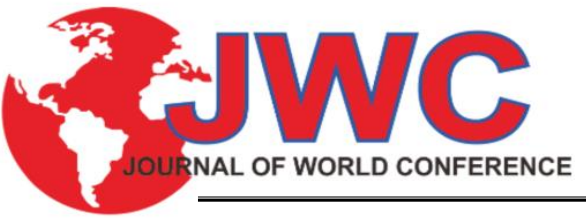

VOLUME 2 | NUMBER 2 | MARCH 2020

Available online at

http://proceedings.worldconference.id.

Sule, O. E., Amuni, S. I., Obasan, K. A., \& Banjo, H. A. (2015). Wages and salaries as a motivational tool for enhancing organizational performance. a survey of selected Nigerian workplace. EuroEconomica, 34(1).

Winarno, M. E. (2018). Buku Metodologi Penelitian.

Zhang, C., Lyu, Y., \& Li, M. (2018). an Exploratory Study on the Relationship Between Executive-Employee Compensation Gap and Environmental Performance: Evidence From Chinese Listed Manufacturing Companies. Malaysian E Commerce Journal, 2(2), 01-04. https://doi.org/10.26480/mecj.02.2018.01.04 